\title{
Heat shock proteins in extracellular signaling
}

\author{
Stuart K. Calderwood \\ Division of Molecular and Cellular Biology, Department of Radiation Oncology, Beth Israel \\ Deaconess Medical Center, Harvard Medical School, Boston MA 02215, USA
}

\begin{abstract}
It has now been clearly demonstrated that heat shock proteins (HSP) can escape from the cytoplasm, enter the extracellular milieu, and indeed travel through the blood stream [1]. But to what end and for what purpose? Do extracellular HSPs utilize the same domains that they employ for their intracellular properties as molecular chaperones, or are alternative domains and functions involved? Currently we have some clues regarding the extracellular functions of HSPs that suggest to us roles in inflammation, in the immune response, and in mediating the survival of neurones [1]. However, to clearly define their role in cell signaling and tissue physiology, it is desirable that we understand the behavior of extracellular HSPs at the molecular level. Crucial questions include: how do HSPs cross the plasma membrane, leave the cytoplasm, and enter the extracellular compartments, and how is extracellular HSPs sensed and taken up by target cells?
\end{abstract}

The original findings that HSPs can be found in the extracellular fluids initially caused some bewilderment, as they lack the signal sequences associated with classically secreted proteins and their release is not inhibited by agents that block transport through the ER/Golgi pathway. It was thus assumed that such extracellular HSP originated in dead cells undergoing lysis [2-5]. However, recent studies point to "non-canonical" physiological secretion pathways that have been identified for release of other proteins lacking a conventional signal sequence [6].Therefore mechanisms for and approaches to the study of HSP secretion are discussed in the current issue in the articles by Mambula et al., Ireland et al., and Asea. It is also desirable to increase the release of HSPs to amplify responses to molecular chaperone-based immunotherapy; increased secretion of such HSPs leads to enhanced immunity [7]. Beachy et al. therefore discuss approaches that can be used to engineer secretable forms of molecular chaperones in their article. Cellular responses to low concentrations of molecular chaperones found in extracellular fluids require a reasonably high-affinity cell surface recognition structure. The existence of HSP receptors has thus been proposed. Cell surface receptors for molecular chaperones are discussed by Calderwood et al. As scavenger receptors, originally discovered as the receptors for chemically modified proteins such as oxidized low density lipoprotein, are emerging as important HSP receptors [7], such receptors are discussed in depth by Plüddemann et al. and. Inoue and Sawamura. In addition, approaches employed in the search for the elusive chaperonin 60 (Hsp60) receptor are described in the article by Henderson and Mesher. However, non-receptor mechanisms may also be involved in HSP uptake, particularly in cells such as dendritic cells adapted for endocytosis of extracellular structures and for sampling the extracellular environment. Pockley et al. discuss non-receptor mediated mechanisms for HSP uptake. Finally, it appears

(C) 2007 Elsevier Inc. All rights reserved.

Fax (617) 632 0635. scalderw @ bidmc.harvard.edu.

Publisher's Disclaimer: This is a PDF file of an unedited manuscript that has been accepted for publication. As a service to our customers we are providing this early version of the manuscript. The manuscript will undergo copyediting, typesetting, and review of the resulting proof before it is published in its final citable form. Please note that during the production process errors may be discovered which could affect the content, and all legal disclaimers that apply to the journal pertain. 
in addition that a fraction of the extracellular HSPs are displayed on the cell surface, particularly in cancer cells. Mechanisms involved in the membrane localization of Hsp70 and its role in immunotherapy are discussed in the article by Multhoff.

This issue aims to give the reader an introduction to this emerging field of extracellular molecular chaperones. We have attempted to discuss current knowledge and outstanding questions in this area, as well as to give investigators entering the field an understanding of technical approaches to these problems.

\section{References}

1. Calderwood SK, Mambula SS, Gray PJ Jr, Theriault JR. FEBS Lett. 2007

2. Hightower LE, Guidon PT. J Cell Physiol. 1989; 135:257-66. [PubMed: 2918030]

3. Tytell M, Greenberg SG, Lasek RJ. Brain Res. 1986; 363:161-4. [PubMed: 3947949]

4. Pockley AG. Circulation. 2002; 105:1012-7. [PubMed: 11864934]

5. Srivastava P. Cancer Immun. 2003; 3:4. [PubMed: 12812464]

6. Mambula SS, Calderwood SK. J Immunol. 2006; 177:7849-57. [PubMed: 17114456]

7. Daniels GA, Sanchez-Perez L, Diaz RM, Kottke T, Thompson J, Lai M, Gough M, Karim M, Bushell A, Chong H, Melcher A, Harrington K, Vile RG. Nat Biotechnol. 2004; 22:1125-32. [PubMed: 15300260] 